\title{
A Benign Pathology Mimicking Multiple Bone Metastasis on F-18 FDG-PET/CT: Brown Tumor
}

\author{
F-18 FDG-PET/CT'de Multiple Kemik Metastazını Taklit \\ Eden Benign Bir Patoloji: Brown Tümör
}

Ozlem Sahin ${ }^{1}$,

Ahmet Eren Sen ${ }^{1}$,

Zeynep Aydin ${ }^{1}$,

Bugra Kaya ${ }^{1}$

${ }^{1}$ Necmettin Erbakan University, Meram

Faculty of Medicine, Department of Nuclear Medicine, Konya, Turkey

Geliş Tarihi/Received: 22 May 2018

Kabul Tarihi/Accepted: 24 August 2018

Address correspondence to: Ozlem Sahin, Necmettin Erbakan University Meram Faculty of Medicine, Department of Nuclear Medicine, Konya, Turkey.

e-mail: drozlemsahin@gmail.com

ORCID

Ozlem Sahin

https://orcid.org/0000-0001-5318-0066
Öz

Brown tümörler uzun süreli hiperparatiroidinin nadir bir komplikasyonu olarak ortaya çıkabilen, benign ancak lokal agresif seyreden tümörlerdir. Klinik ve radyolojik olarak kemik metastazları ile karışabilirler F-18 FDG PET/CT'de Brown tümörler tıpkı metastatik kemik lezyonları gibi artmış metabolik aktivite gösterirler. Çalışmamızda multiple kemik metastazı ön tanısı ile primer odak aramak için PET/CT çekilen, görüntülerde primer odak saptanmayıp paratiroid lojlarında artmış FDG tutulumu görülmesi nedeni ile Brown tümörden şüphelenilen ve ileri tetkiklerle tanısı doğrulanan bir hasta sunulmuştur. Bu olgu sunumu ile klinik ve radyolojik olarak kemik metastazı düsünülen hastalarda Brown tümörünün de ayırıcı tanıda akılda tutulması gerektiğini vurgulamayı amaçladık.

Anahtar Kelimeler: Brown tümör, FDG-PET/CT, kemik metastazı

\section{Abstract}

Brown tumors are benign, but locally aggressive tumors that may emerge as a rare complication of prolon ged hyperparathyroidism. They may be clinically and radiologically confused with bone metastases. Brown tumors show increased metabolic activity on F-18 FDG-PET/CT just as metastatic bone lesions. In this study, we present a patient who underwent PET/CT to seek a primary focus with the presumed diagnosis of multiple bone metastasis, and Brown tumor was suspected because no primary focus was detected on imaging and increased FDG uptake was seen in parathyroid locations, and the diagnosis was confirmed with further investigations. Herein, we aimed to underline emphasize that Brown tumors should be kept in mind in the differential diagnosis in patients who are clinically and radiologically considered to have bone metastasis.

Key words: Brown tumor, FDG-PET/CT, bone metastasis

\section{INTRODUCTION}

Brown tumor is a rare complication which develops due to the bone resorption caused by excessive osteoclastic activity in prolonged hyperparathyroidism. The incidence of Brown tumors is 3\% in primary hyperparathyroidism and $1.5 \%$ in secondary hyperparathyroidism. However, since secondary hyperparathyroidism is more common in general population, patients with Brown tumors are rather the patients who have secondary hyperparathyroidism $(1,2,3)$. The most common cause of secondary hyperparathyroidism is chronic renal failure. Early diagnosis of hyperparathyroidism decreases the incidence of Brown tumors (4).

Over production of parathormone increases osteoclastic activity, leading to overall bone loss known as osteitis fibrosa cystica, as a result of subperiosteal resorption. Microfractures and secondary hemorrhage develop as the process gets longer, stimulating macrophages and formation of fibrous tissue, and hemosiderin accumulates within the osteolytic areas. Hemosiderin pigment gives the tumor its characteristic brown color $(1,5)$.

Brown tumors are benign, but locally aggressive tumors. Clinically soft tissue swelling, pathologic fractures, and pain may be seen. The most commonly involved bones are ribs, clavicles, pelvic bones, femur, and mandibula (6). Vertebral involvement is more infrequent compared to the other bones in Brown tumors (1). These tumors may be monostotic or polyostotic (3). X-ray radiograph and CT are the primarily used modalities for the visualization of Brown tumors. F-18 FDG-PET/CT and bone scintigraphy provide a higher sensitivity especially in 
demonstration of the lesion diffusiveness especially in polyostotic tumors and give the lesion map in the most correct way $(7,8,9)$. Brown tumors manifest with 'hypermetabolic' bone lesions that show increased FDG uptake on PET/CT imaging $(3,4,7,8)$. Similarly, increased radioactivity uptake due to reactive osteoblastic activity is seen in the bone lesions on bone scintigraphy in these patients (9). Brown tumors may exhibit common clinic, radiologic, and histopathologic characteristics with osteoclastoma, multiple myeloma, and bone metastases (6). Metastatic bone tumors with unknown primary and Brown tumors may be clinically and radiologically confused (3).

Herein, a case of Brown tumor in a patient who underwent F-18 FDG-PET/CT in order to determine primary focus with the presumed diagnosis of metastatic mass in the vertebra and multiple bone metastasis.

\section{CASE}

A 48-year-old female patient presented with the lower back and right leg pain, and Lumbar MRI ordered showed a tumoral lesion in L1 vertebra which narrowed the spinal canal, and compressed the spinal cord (Figure $1 \mathrm{~A}$ and $\mathrm{B}$ ). The lesion was of heterogeneous hypointense appearance on T1 and T2 weighted sequences, there was marked enhancement on contrast enhanced imaging. Because there were lesions of similar nature in the corpus of L1 and L4 vertebrae, it was considered as metastatic and the patient was asked to have F-18 FDG-PET/CT for the primary diagnosis. Besides the mass observed in L1 and L4 vertebrae on PET/CT, Iytic-expansile lesions with increased FDG uptake were also seen in the mandibula, clavicles, sternum, scapulas, both humeri, ribs, and pelvic bones (Figure $2 \mathrm{~A}$ and B). In
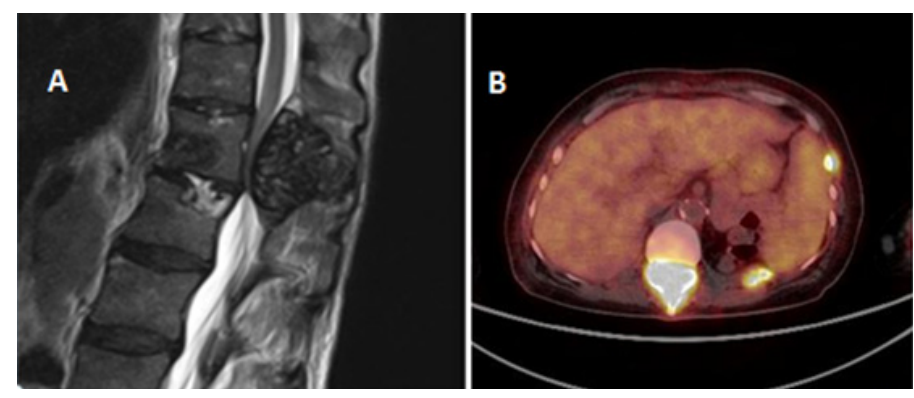

Figure 1. (A) Tumor that compresses the spinal canal in the $L 1$ vertebra on MRI (B) Increased FDG uptake mimicking malignancy in this lesion on FDG PET/CT

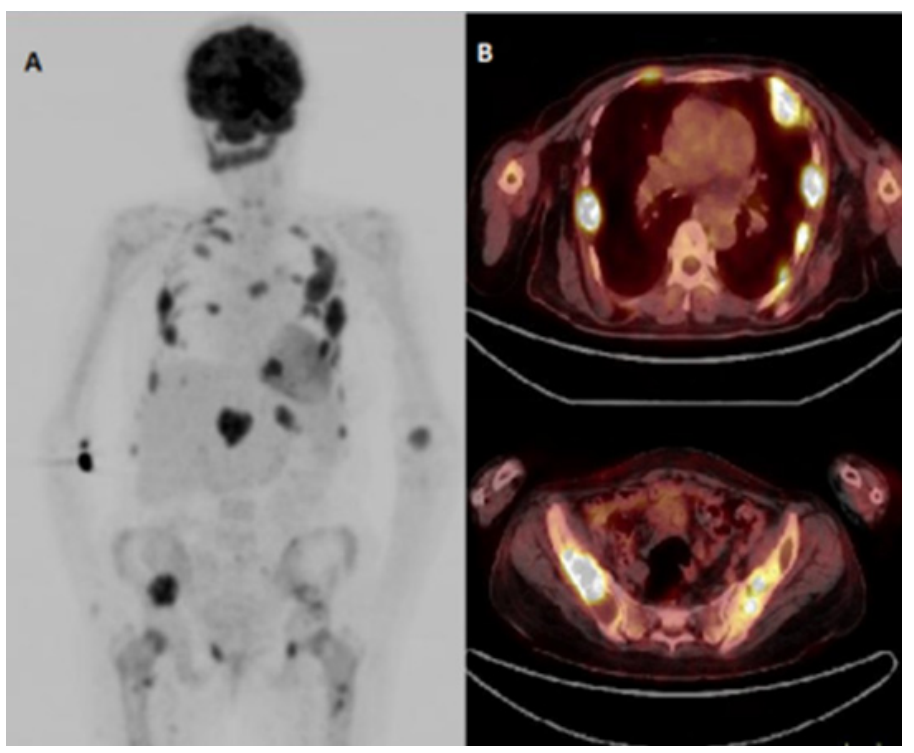

Figure 2. (A) Increased FDG uptake mimicking multiple bone metastases on maximum intensity projection (MIP) of FDG PET/CT image; and (B) cross-sectional PET/CT images

addition, increased radioactivity of low density was observed in the parathyroid gland posterior to both thyroid glands. Apart from these, there was no any finding compatible with a primary tumor that may cause bone metastases. When clinic of the patient was questioned again, it was learned that she had undergone bilateral nephrectomy operation due to polycystic kidney 8 years ago, and she had dialysis for 10 years. Laboratory results of the patient were as follows: IPTH: $1313 \mathrm{pg} / \mathrm{mL}$ (N: 1-67), Ca: 11.46

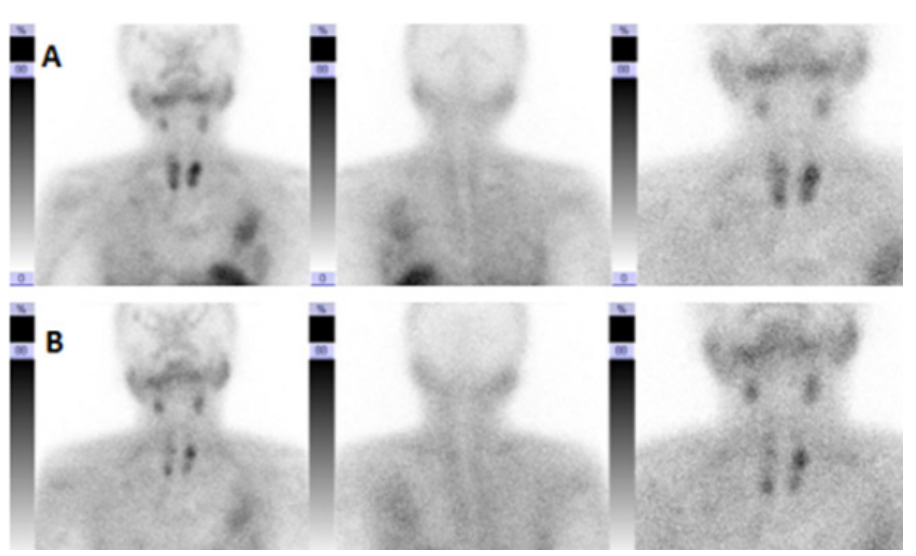

Figure 3. Tc- $99 \mathrm{~m}$ MIBI parathyroid scintigraphy findings consistent with parathyroid hyperplasia in early $(A)$ and late (B) static images 
$\mathrm{mg} / \mathrm{dL}(\mathrm{N}: 8.4-10.2), \mathrm{P}: 5.54 \mathrm{mg} / \mathrm{dL}(\mathrm{N}: 2.3-4.7)$, ALP: $487 \mathrm{U} / \mathrm{L}(\mathrm{N}: 40-150)$. In light of the laboratory results, the patient was considered to have Brown tumor due to secondary hyperparathyroidism., Tc$99 \mathrm{~m}$ methoxyisobutyl isonitrile (MIBI) parathyroid scintigraphy was performed in order to confirm the diagnosis, and parathyroid hyperplasia findings were observed. In addition, MIBI uptake was observed in Brown tumor localization in the area corresponding to the ribs anterior to the left hemithorax (Figure $3 \mathrm{~A}$ and $B$ ). Patient was operated later on because of the compression to the spinal canal. In the histopathologic examination of the case, multinuclear giant cells and fibroblast like spindle cells causing resorption in bone trabeculae were observed.

\section{DISCUSSION}

Brown tumor is the late period bone finding of hyperparathyroidism (5). Although it progresses locally aggressive, Brown tumor is not a real tumor. Clinically these tumors emerge as slow growing painful tumors. Brown tumors are often seen at the 4th and 5th decades (5). Vertebral involvement is more infrequent compared with the other regions. Surgical intervention may be needed if the tumor compresses the spinal canal (1). In our case also the patient was operated later on because of the compression to the spinal canal.

Brown tumors may be confused with primary bone tumors, multiple myeloma, and bone metastases because they can exhibit common clinical and radiological features $(3,6)$. Brown tumors may exhibit common clinic, radiologic, and histopathologic characteristics with osteoclastoma, multiple myeloma, and bone metastases (6). Metastatic bone tumors with unknown primary and Brown tumors may be clinically and radiologically confused (3).

Histopathologically, Brown tumors are most often confused with giant cell tumors (GCT), also called osteoclastoma. The fibroblastic tissue filling the bone resorption sites in the Brown tumor contains numerous osteoclast-like multinuclear giant cells. Although the presence of these giant cells and stromal mononuclear cells overlap with GCT, there are some microscopic differences. Round stromal mononuclear cells are observed in GCT whereas spindle stromal mononuclear cells are observed in Brown Tumor. While giant cells tend to uniformly distributed in GCT, they are usually arranged in clusters in CT (3). Histopathologically, the differential diagnosis of these two tumors may not be made. Clinical and laboratory findings of hyperparathyroidism also should be definitely evaluated (10). The treatment of Brown tumor is partial or complete resection of the parathyroid gland. Spontaneous tumor regression is followed by the operation (10). The treatment of GCT is a surgical excision of the tumor.

F-18 FDG-PET/CT is widely used in distinguishing the malignant and benign lesions. Malignant tissues show increased FDG uptake due to their high glucose metabolism. It is known that high FDG uptake is seen in the benign conditions such as inflammation and infection due to the increased metabolism. In addition, although showing benign properties, giant cell reperative granuloma, aneurysmal bone cyst and Brown tumors present high amount of FDG uptake (5). Intracellular glucose metabolism of macrophages is thought to play a role in increased FDG uptake in Brown tumors. F-18 FDG-PET/CT shows lesion mapping with a high sensitivity, as well as is quite practicable in evaluation response to treatment (5).

Brown tumors may be confused with bone metastasis in practice. In our case also the patient was clinically and radiologically considered to have multiple bone metastasis. However, no primary lesion was observed on PET/CT and increased FDG uptake in parathyroid locations, suggesting probability of Brown tumor. Findings compatible with parathyroid hyperplasia were found on Tc-99m-MIBI dual phase parathyroid scintigraphy. Brown tumor diagnosis of the patient operated due to the compression to the spinal canal was also pathologically confirmed.

In conclusion; if no primary lesion was observed when evaluating the PET/CT imaging ordered radiologically considering bone metastasis, Brown tumor should also be kept in mind, and patient's history, clinical picture and laboratory results should be questioned for hyperparathyroidism.

Conflict of interest: Authors declare that there is no conflict of interest between the authors of the article.

Financial conflict of interest: Authors declare that they did not receive any financial support in this study.

Address correspondence to: Ozlem Sahin, Necmettin Erbakan University Meram Faculty of Medicine, Department of Nuclear Medicine, Konya, Turkey,

Postal code: 42090

Telephone: 05052401292

e-mail: drozlemsahin@gmail.com 


\section{REFERENCES}

1. Kızmazoğlu C, Sevin IE, Kalemci O, et al. Kronik böbrek yetmezliği olan hastada kemik metastazını taklit eden Brown tümör. Sinir Sistemi Cerrahisi Derg 2014;4(3):138-42

2. Turan E, Kargin S, Nazik EE, et al. Akut paratiroid krizi ile başvuran kistik paratiroid adenomu. Selçuk Tıp Derg 2016;32(2):49-51.

3. Gedik GK, Ata O, Karabagli P, et al. Differential diagnosis between secondary and tertiary hyperparathyroidism in a case of a giant-cell and Brown tumor containing mass. Findings by $99 \mathrm{mTC}-\mathrm{MDP}, 18 \mathrm{~F}-\mathrm{FDG}$ PET/CT and $99 \mathrm{mTC}-\mathrm{MIBI}$ scans. Hell J Nucl Med. 2014;17(3): 214-7.

4. Penhoat MG, Drui D, Ansquer C, et al. Contribution of 18-FDG $\mathrm{PET} / \mathrm{CT}$ to Brown tumor detection in a patient with primary hyperparathyroidism. Joint Bone Spine 2017;84(2):209-12.

5. Sager S, Aliyev A, Halac M, et al. Positron emission tomography/computed tomography imaging of Brown tumors mimicking multiple skeletal metastases in patient with primary hyperparathyroidism. Indian J Endocrinol Metab 2012;16(5):850-2.
6. Liu YJ, Frauenhoffer EE, Walker E, et al. A case report of Brown tumor in a patient with chronic renal failure and renal cell carcinoma. Diagn Cytopathol 2018;46(4):355-61.

7. Guy MS, Jacob C, McDonald SD, et al. 18F-FDG PET/CT metabolic variability in functioning oncocytic parathyroid adenoma with Brown tumors. Clin Nucl Med 2014;39(4):3935.

8. Uslu L, Çalışkan A, Sağer $S$, et al. Preoperative and postoperative 18-FDG PET/CT and bone scintigraphy images in a patient with parathyroid adenoma. Clin Nucl Med 2013;38(6):456-8.

9. Yapar AF, Aydin M, Reyhan M, et al. Simultaneous visualization of a mandibular Brown tumor with a large parathyroid adenoma on Tc-99m MIBI imaging. Clin Nucl Med 2005;30(6):433-5.

10. Panagopoulos A, Tatani I, Kourea HP, et al. Osteolytic lesions (brown tumors) of primary hyperparathyroidism misdiagnosed as multifocal giant cell tumor of the distal ulna and radius: A case report. J Med Case Rep 2018;12(1):176. 